\title{
GREBEG PANCASILA: PERINGATAN LAHIRNYA PANCASILA DAN MAKNA NILAI FILOSOFISNYA
}

\author{
Febriana Novitasari ${ }^{1}$, Ahmad Suhadak $^{2}$, Ayu Anggraini ${ }^{3}$, Agung Wiradimadja, M.Pd ${ }^{1 *}$ \\ agung.wiradimadja.fis@um.ac.id \\ ${ }^{1}$ Prodi Pendidikan IPS, Fakultas IImu Sosial, Universitas Negeri Malang \\ 2Jurusan Seni dan Desain, Fakultas Sastra, Universitas Negeri Malang \\ 3 Jurusan Akuntansi, Fakultas Ekonomi, Universitas Negeri Malang \\ Diterima 23 Oktober 2020, dipublikasikan 30 April 2021
}

\begin{abstract}
Abstrak
Kota Blitar memiliki rekam jejak tradisi budaya yang beranekaragam. Grebeg Pancasila merupakan sebuah tradisi budaya Kota Blitar untuk memperingati hari lahirnya Pancasila. Tradisi ini hadir atas gagasan dari para seniman serta para budayawan di Kota Blitar, yang khawatir dikarenakan setiap tanggal 1 Juni tidak diperingati sebagai hari lahir Pancasila. Tradisi Grebeg Pancasila memiliki nilai filosofis yang sangat penting untuk dikaji. Nilai filosofis yang terkandung dalam tradisi ini perlu untuk dipahami dan diamalkan dalam kehidupan sehari-hari. Penelitian ini mencoba untuk mengkaji tradisi Grebeg Pancasila di Kota Blitar dengan metode studi literatur yang disajikan secara kualitatif. Dengan melakukan pengkajian tradisi Grebeg Pancasila secara mendalam akan dapat menemukan makna tersitat yang terkandung dalam prosesi Grebeg Pancasila. Dengan mengetahui filosofi yang dimiliki tradhisi Grebeg Pancasila mampu memberikan wadah literasi kebangsaan kepada masyarakat Indonesia.
\end{abstract}

Kata Kunci: Tradisi, Grebeg Pancasila, Nilai Filosofis

\section{PENDAHULUAN}

Indonesia merupakan bangsa multikultural dengan berbagai macam sejarah dan kebudayaan yang berkembang. Kebudayan yang dimiliki adalah salah satu warisan yang unggul karena keunikannya dan memiliki kebudayaan yang berbeda dengan budaya pada negara lainnya. Kebudayaan yang dihasilkan berasal dari akulturasi budaya sesuai perkembangan zaman dan membentuk kearifan lokal. Kebudayaan sendiri mempunyai fungsi sebagai, pattern of behavior dan pattern for behavior. Pattern of behavior (pola dari perilaku), melakukan tindakan berdasarkan sistem nilai yang diyakini kebenarannya. Sedangkan pattern for behavior (pola untuk berperilaku), dimana kebudayaan dapat dijadikan sebagai sistem nilai yang menjadi pedoman hidup masyarakat.

Kebudayaan nasional Indonesia berlandaskan Pancasila menekankan pada persatuan. Kedudukan Pancasila sebagai falsafah dan pandangan hidup bangsa (Kaelan, 2002). Maka dari itu, kebudayaan perlu terus dimonitoring sebagai sarana penanaman nilai-nilai Pancasila. Melihat masyarakat Indonesia yang saat ini kurang menghayati nilai-nilai Pancasila sebagai landasan kehidupan bernegara. Terlebih, nilai Pancasila sering dihadapkan dengan sikap intoleransi antar umat beragama yang membuat keduanya saling bertentangan. Begitupun dengan semangat nasionalisme yang mulai menurun dalam jiwa anak muda penerus bangsa. Cita-cita nasionalisme para pendiri bangsa yang tertuang dalam pembukaan Undang-Undang Dasar 1945 saat ini tidak menggugah semangat masyarakat dalam berbangsa dan bernegara. Buktinya, banyak terjadi gejolak sosial dimana-mana. Kemajemukan budaya dan masyarakat Indonesia dapat memicu potensi konflik jika tidak diimbangi kepedulian sosial dan sikap toleran.

UUD NKRI 1945 Pasal 32 menyatakan bahwa, "Pemerintah memajukan kebudayaan nasional Indonesia," dimana kebudayaan menjadi pedoman nilai, aturan dan mencerminkan simbol identitas bangsa. Maka dari itu, pemerintah turut andil dalam memajukan kebudayaan Indonesia. Tak terkecuali Pemerintahan Kota Blitar, ikut berpartisipasi aktif dalam memajukan budaya lokal, sebagai upaya untuk mengantisipasi terkikisnya nilai budaya. Blitar merupakan pemerintahan kota yang terus 
berkembang. Perkembangan kota merupakan tuntutan yang semakin sulit dikontrol sehingga menimbulkan persoalan yang mengakibatkan kemunduran.

Kemunduran lingkungan kota sering disebut dengan istilah "Urban Environment Degradation" telah meluas dibelahan kota dunia (Bintarto, 1989). Kemunduran ini dapat dilihat dari salah satu aspek kehidupan sosial-masyarakat (environmental degradation of societal nature). Bintarto (Bintarto, 1989) menjelaskan bahwa kesibukan masyarakat kota menjadi penyebab kemunduran karena dapat mengurangi perhatian terhadap sesamanya, jarang sekali terjadi kontak sosial. Kontak sosial masyarakat kota didasarkan pada impersonal, segmental, dan utilitar (Daldjoeni, 1978). Orang memandang sesamanya berdasarkan perananan (fungsionalis) tertentu. Melihat pendapat tersebut yang selaras dengan kehidupan masyarakat Blitar, dapat dikatakan bahwa masyarakat Blitar mulai menunjukkan adanya sikap individualisme. Perwujudan sikap individualis masyarakat kota Blitar dapat tercermin melalui ungkapan fisik, berupa batas ruang (terrytory). Misalnya, pemasangan pagar halaman depan rumah yang mencerminkan ketertutupan. Sikap individualis lain juga ditunjukkan dalam bentuk perilaku masyarakat. Sebagai contoh, kurang akrabnya antar tetangga karena memang masing-masing masyarakat memiliki kesibukan yang berbeda.

Kota Blitar disebut juga kota Proklamator, dimana tempat disemayamkannya tokoh perjuangan kemerdekaan, Ir. Soekarno. Bung Karno adalah bapak pencetus lahirnya Pancasila. Lahirnya Pancasila yakni pada tanggal 1 Juni 1945, hal ini ditandai dengan momentum sidang BPUPKI pada pidato Bung Karno. Bung Karno sendiri merupakan bapak patriotisme Kota Blitar. Sebagai wujud penghormatan kepada Bung Karno dan Pancasila, pemerintah Kota Blitar menyelenggarakan tradisi Grebeg Pancasila.

Grebeg Pancasila merupakan sebuah tradisi budaya dan perayaan dalam bentuk festival untuk memperingati hari lahirnya Pancasila. Tradisi ini digagas oleh para seniman dan budayawan di Kota Blitar yang khawatir, karena sebelumnya pada masa Orde Baru tahun 1970, tanggal 1 Juni tidak diperingati bahkan sebagai hari lahirnya Pancasila. Maka dari itu, para seniman dan budayawan Kota Blitar menggelar tradisi Grebeg Pancasila sebagai tradisi budaya untuk mengingat hari lahirnya Pancasila.

Pentingnya mengkaji tradisi Grebeg Pancasila adalah untuk memahami makna filosofis tradisi tersebut dan nilai-nilai yang terkandung. Sudah sangat tentu, menjaga dan melestarikan kebudayaan bangsa sangat penting. Mengingat kebudayaan dan tradisi ini memiliki makna dan nilai nasionalisme, agar tidak tergerus kebudayaan asing. Generasi penerus bangsa perlu untuk melestarikan keragaman budaya.

Penelitian ini bukanlah penelitian satu-satunya, pada peneltian sebelumnya bahasan studi tentang Grebeg Pancasila telah banyak dilakukan. Pada penelitian yang dilakukan oleh Khotimah (Khotimah, 2011) membahas tentang upaya untuk mengembangkan nilai-nilai nasionalisme yang terkandung dalam tradisi Grebeg Pancasila. Sedangkan penelitian Putriana (Putriana \& Warsono, 2019) mengkaji tentang tardisi Grebeg Pancasila sebagai sarana untuk menanamkan nilai-nilai Pancasila. Terakhir, penelitian oleh Zummi (Zummi, 2016) yang membahas mengenai keterkaitan tradisi Grebeg Pancasila terhadap pembelajaran IPS.

Dari ketiga peneliti terdahulu, sayangnya belum ada yang mengkaji Nilai-nilai Filosofis kebudayaan grebek Pancasila. Penelitian ini ditujukan untuk mengisi kekosongan penelitian tentang grebek Pancasila, yaitu mengkaji nilai filosofis yang terdapat pada tradisi tersebut.

\section{METODE}

Penelitian dilakukan dengan pencarian data primer yaitu buku-buku sumber literatur yang hanya dapat ditemukan di UPT Perpustakaan Makam Bung Karno Kota Blitar. Penelitian ini menggunakan metode kualitatif deskriptif, yang bertujuan untuk mendeskripsikan nilai-nilai filosofis yang terdapat dalam tradisi Grebeg Pancasila secara objektif, dengan teknik pengumpulan data menggunakan kajian literatur. Variabel dan definisi operasional dalam penelitian yang digunakan yaitu nilai-nilai filosofis sebagai variabel independen (bebas) dan tradisi Grebeg Pancasila di Kota Blitar sebagai variabel dependen (terikat). Pengumpulan data dilakukan dengan cara narrative review 
dengan kajian literature yang mendalam untuk mendapatkan data berdasarkan maksud dan tujuan penelitian.

Penelitian ini menggunakan teknik analisis model Miles dan Huberman. Analisis data dilakukan model ini dilakukan secara interaktif dan memungkinkan peneliti untuk berulang kembali mengambil data hingga data yang didapatkan.

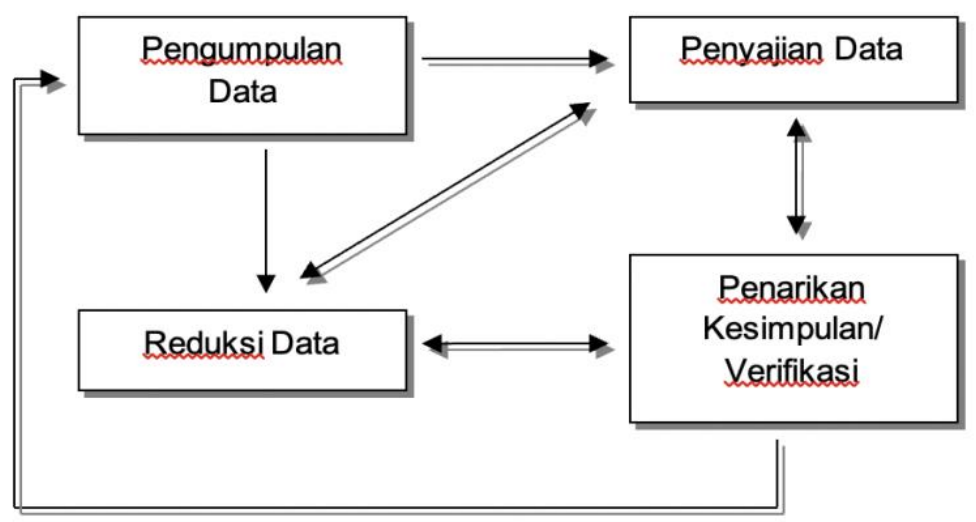

Gambar 1. Diagram alur tahapan penelitian (Miles \& Huberman, 1992: 16).

\section{HASIL DAN PEMBAHASAN}

Memperingati berasal dari kata dasar ingat, memiliki pengertian mengingat sesuatu peristiwa atau momen. Ingat harus didasari mengerti, memahami, menghayati. Melibatkan lahir, pikir dan batin. Memperingati Hari lahirnya Pancasila melalui Grebeg Pancasila di Kota Blitar, merupakan salah satu wujud peringatan hari besar nasional yang dilaksanakan dengan latar belakang budaya lokal namun memiliki bobot dan cakupan nasional. Sehingga dalam proses pelaksanaannya harus didasari oleh kesadaran bahwasanya warga Kota Blitar adalah bagian integral dari bangsa Indonesia. Peringatan ini harus mampu menjadi sebuah acara yang mampu memberi inspirasi kepada bangsa Indonesia untuk lebih mengenal sejarahnya sendiri, karakternya sendiri dan tujuan hidupnya sendiri melalui pembelajaran sepanjang hayat didalam acara Grebeg Pancasila (Rohmah, 2019).

Sebagai sebuah proses komunikasi, Grebeg Pancasila memuat serangkaian informasi yang didemonstrasikan sedemikian rupa untuk ditonton khalayak ramai selanjutnya menjadi tuntunan hidup. Sebuah proses komunikasi yang harus memiliki efektifitas. Efektifitas ini harus ditemukan oleh segenap kreator acara ini. Indikator efektifitas komunikasi harus ditentukan secara realitis obyektif. Indikator misalnya, setelah mengikuti proses acara Grebeg Pancasila, baik aktif ataupun pasif, masyarakat diharapkan dapat memahami sejarah, nilai nilai dan mampu mensintesakan nilai-nilai tersebut secara dinamik dan visioner mampu menjawab tantangan yang terjadi saat ini dan visioner pada masa masa mendatang. Standart minimal dari kesuksesan Grebeg Pancasila adalah segenap masyarakat mau membaca, memahami, mengerti kejadian sejarah 1 Juni 1945. Selanjutnya pemahaman itu menjadi pintu pembuka untuk menelusuri kemasa lalu dan sekaligus menggambarkan kemasa depan secara visioner.

Sebagai sebuah proses pendidikan, Grebeg Pancasila harus mampu menciptakan perubahan cara hidup, cara berpikir dan cara bertindak bertingkah laku. Konsep perubahan dari suatu kondisi tertentu menjadi kondisi tertentu. Kondisi akhir yang diinginkan adalah kondisi yang sesuai serta sejalan dengan nilai yang terkandung dalam Pancasila dan Kemerdekaan. Manusia sebagai pembelajar dan pembangun harus memiliki sifat kritis dan selalu melakukan perbaikan. Melalui pemikiran ini diusahalan untuk menemukan segala kekuarangan dan kesalahan. Bukan untuk dijadikan komoditas pembulian namun dijadikan sebagai penentuan titik awal untuk menuju ideal yang diinginkan.

Tahapan dalam pelaksanaan Tradisi Grebeg Pancasila terdiri dari lima tahapan, yakni: Bedholan Grebeg, Tirakatan, Upacara Budaya, Kirab Gunungan Limo, dan Kenduri Pancasila (Sumitrasari, 2012). 


\section{Prosesi Pertama Ritus Bedholan Grebeg}

Ritus Bedholan Grebeg atau Bedhol Pusaka Nagari adalah prosesi pertama pada pelaksanaan Grebeg Pancasila di Kota Blitar yang dilaksanakan tanggal 31 Mei malam di rumah dinas Walikota Blitar. Prosesi tersebut bertujuan untuk mengambil pusaka nagari dari rumah dinas ke kantor dinas Walikota Blitar, dimana sebelumnya pusaka nagari tersebut telah dileremkan semalaman dan selanjutnya akan diarak bersama Gunungan Lima pada tanggal 1 Juni menuju Makam Bung Karno. Pusaka nagari diarak oleh Bregodo Siji dan Bregodo Enem yang menggunakan pakaian tradisional Majapahit yaitu beskap lengkap; Bregodo Patang Puluh Lima yang menggunakan pakaian prajurit majapahit; dan Prajurit Trisakti. Pelaksanaan prosesi ini, selain menggunakan pakaian daerah juga menggunakan bahasa Jawa sebagai wujud pelestarian budaya daerah di Indonesia.

Pada prosesi ini dilakukan arak - arakan lima pusaka yaitu bendera merah putih, teks Pancasila, lambang burung garuda, teks pidato Bung Karno pada tanggal 1 Juni 1945, dan foto Bung Karno. Hal tersebut mencerminkan adanya nilai Nasionalisme didalamnya. Nasionalisme merupakan sebuah paham untuk mencintai bangsa dan negaranya sendiri. Nasionalisme juga bisa dianggap suatu sikap masyarakat yang memiliki budaya, wilayah, cita-cita dan tujuan yang sama. Hal tersebut menumbuhkan rasa adanya kesetiaan masyarakat yang mendalam kepada bangsanya sendiri. Sehingga, pada prosesi Bedhol Pusaka Nagari ini merupakan wujud kesetiaan dan kecintaan masyarakat di Kota Blitar terhadap bangsa dan negara Indonesia. Selain itu, nilai gotong royong pada prosesi ini tidak dapat dilupakan. Hal ini tercermin dari adanya kerjasama antar pelaku kegiatan. Pada prosesi Bedhol Pusaka Nagari, arak-arakan dilakukan oleh Bregodo Siji, Bregodo Enem, Bregodo Patang Puluh Lima, dan Prajurit Trisakti. Dimana didalamnya masyarakat di Kota Blitar saling bekerja bersama-sama dan bahu membahu agar kegiatan berjalan dengan lancar, yang menandakan adanya nilai gotong royong dan Persatuan didalamnya.

Urutan prosesi ini sebenarnya menyiratkan sebuah makna yang bertentangan antara keinginan ideal dan kenyataan yang terjadi. Keinginannya adalah Pancasila bisa hidup ditengah masyarakat berbangsa dan bernegara. Namun kenyataan justru pusaka Nagari Pancasila dikembalikan kepada Bung Karno dan dibawa kekuburanya. Pancasila yang seharusnya dipelajari, dipahami, dihayati dan diamalkan oleh segenap bangas Indonesia justru dikembalikan kepada Bung Karno di Makamnya. Entah sadar atu tidak sebenarnya Pancasila sedang dibawa kekuburanya, dimana artinya sedang dibumikan atau dikembumikan. Grebeg Pancasila pada kenyataannya membawa Pancasila kekuburan dan mengantarkan pulang atau memulangkan Pancasila kepada Bung Karno.

Pusaka Pancasila secara simbolik diambil dan dibawa ketengah alun-alun sebagai simbol kancah ekspresi perjuangan masyarakat berbangsa dan bernegara untuk mencapai cita citanya. Dialun-alun itulah Pancasila digrebeg, artinya diproses secara koleksitf kebangsaan untuk dihidupkan kembali. Dipelajari kembali, dipahami, dimengerti, diresapi dan diimplementasikan oleh seluruh komponen bangsa, secara berkesinambungan untuk direvitalisasikan kembali oleh seluruh masyarakat Indonesia. Pancasila dioperasionalkan oleh masyarakat ataupun oleh segenap aparat negara dan pemerintah.

Penggunaan Pakaian majapahit dan pemakaian basaha Jawa justru membuat sebuah kemunduran dari proses untuk menjadi Indonesia. Pancasila adalah pemersatu bangsa dan dasar negara serta karater dan tujuan hidup. Bangsa Indonesia hidup menuju masa depan dan bukan untuk kembali kemasa lalu. Majapahit bukan Indonesia dan Indonesia bukan Majapahit. Perbedaan antara feodalisme dan sistem demokrasi sangat terasa disini. Majapahit mempersatukan Indonesia dengan invasi. Bangsa Indonesia mempersatukan diri dengan proses bersama dan sukarela dengan salah satu tonggaknya adalah Sumpah Pemuda. Bahasa sebaiknya digunakan dalam dua bahasa secara seimbang. Bicara Pancasila adalah bicara nasionalisme yang artinya bisa menerima dan diterima oleh seluruh masyarakat Indonesia, dimana bahasa pemersatu kita adalah Bahasa Indonesia.

Salah satu properti yang diarak adalah Teks atau naskah pidato Bung Karo tentang Lahirnya Pancasila 1 Juni 1945. Diduga sebagian besar peserta atau masyarakat warga kota Blitar khususnya dan bangsa Indonesia pada umumnya tidak pernah, atau belum pernah membaca pidato tersebut. Teks tersebut hanya untuk simbolis semata-mata namun tidak ada prosesi menuju pencerdasan masyarakat secara kolekstif berbasis naskah pidato tersebut. Tanpa membaca, memahami, mengerti, 
meresapi dan mengimplemetasikan nilai dalam pidato Lahirnya Pancasila maka makna peringatan untuk mengambil nilai spirit dan menghidupkannya kembali menjadi sebuah usaha yang sia-sia dan hanya menghabiskan tenaga, sementara tidak menambah kecerdsasan literasi masyarakat. Nilai dari peringatan ini perlu ditingkatkan dengan kegiatan literasi untuk meningkatkan kecerdasan masyarakat terhadap nilai-nilai Pancasila melalui pemberdayaan Pidato Lahirnya Pancasila.

\section{Prosesi Kedua Ritus Malam Tirakatan}

Ritus Malam Tirakatan dilaksanakan malam menjelang tanggal 1 Juni di Balai Kusuma Wicitra dengan maksud sebagai perwujudan rasa syukur, renungan, introspeksi diri atas kesalahan - kesalah agar tidak terulang kembali. Prosesi ini melambangkan sebuah renungan, serta penghayatan terhadap pentingnya nilai-nilai Pancasila sebagai nilai luhur Bangsa Indonesia. Prosesi Malam tirakatan diisi dengan mocopatan (nembang lagu menggunakn syair Jawa) atau semaan mocopat Banjaran Bung Karno selama semalam suntuk. Pada prosesi ini juga terdapat uborampe atau sesaji (dalam bahasa jawa dikenal dengan nama sesajen) yang diletakkan di tengah-tengah balai. Sesaji tersebut berisi lilin, pisang raja setandan, bunga setaman, kapur dan sirih, jajan pasar, bubur, tumpeng nasi putih, ayam ingkung, telur rebus, dupa, wewangian, dan kopi hitam (Zummi, 2016).

Malam tirakatan bertujuan untuk memanjatkan doa kepada Tuhan sebagai ucapan rasa syukur, renungan dan introspeksi diri, serta mengirim doa untuk para leluhur. Ritus ini sebagai bentuk penghayatan nilai pertama Pancasila, dimana kita beragama maka harus berdoa dan menyembah kepada Tuhan Yang Maha Esa. Kegiatan ini mencerminkan nilai Religius yang sangat dijunjung tinggi oleh masyarakat di Kota Blitar. Nilai Religius bersifat mutlak karena bersumber pada kepercayaan dan sudah ada sejak manusia diciptakan dan merujuk pada keyakinan manusia akan keberadaa Tuhan. Sesaji yang digunakan dalam ritus ini, dimana bagi masyarakat Jawa dianggap sebagai persembahan kepada leluhur, untuk menunjukkan rasa hormat, dan bersyukur atas pencapaian para leluhur. Hal tersebut mencerminkan nilai Religius dan nilai Nasionalisme bersatu dimana masyarakat Kota blitar masih mencintai dan mempertahankan warisan budaya lokal.

Prosesi Ritus perlu dipertinggi kualitas dan nilainya. Selama ini tirakatan lebih banyak diisi dengan mengisahkan ulang biografi Bung Karno. Lebih penting dan diperluan adalah menggali kembali perjalanan mental spiritual Bung Karno dalam perjalannanya menysun Pancasila. Bung Karno menggunakan metode historis materialisme dialektif utuk menggali dan menyajikan Pacasila sehingga menjadi rumusan- rumusan yang visioner.

Mocopat adalah usaha yang bagus untuk pelestarian budaya daerah, namun penggalian Pancasila oleh Bung Karno tidak menggunakan Mocopat. Pancasila adalah Indonesia maka dari hendaknya mengadopsi seluruh budaya Indonesia. Pancasila memiliki nilai universal seperti kata Bung Karno sendiri yaitu relevan dengan social consciouesnes of man atau sesuai dengan hati nurani manusia diseluruh muka bumi. Narasi Pancasila sebagai dasar ideologi universal sebaiknya didukung dengan penggunaan Bahasa nasional.

\section{Prosesi Ketiga Ritus Upaca Budaya}

Prosesi Ritus Upacara Budaya dilakukan pada pagi hari tepat di tanggal 1 Juni dan bertempat di alun-alun Kota Blitar berkonsepkan seperti upacara militer biasa. Bedanya, pada Upacara Budaya ini terdapat penambahan gerak, musik, busana, bahasa, dan tari tradisional sehingga menambah kesan unik di dalamnya. Acara dikemas dengan sangat menarik dengan sentuhan kebudayaan lokal yang penuh dengan nilai etik dan estetika, tanpa mengurangi kekhidmatan dan makna yang terkandung dalam ritus tersebut. Bahasa yang digunakan pada ritus Upacara Budaya adalah bahasa Jawa, hanya pada saat pembukaan dan sambutan digunakan bahasa Indonesia. Penggunaan bahasa jawa ini juga sebagai wujud pelestarian dan ciri khas sebagai orang Jawa.

Acara inti pada Upacara Budaya adalah pembacaan goro-goro dan puncaknya adalah Sabda Kawedhar yang berisi pesan moral diadakannya Grebeg Pancasila. Isi Goro-goro berbeda tiap tahunnya, dimana pembuatannya didasarkan pada suasana dan keadaan yang terjadi di negara Indonesia atau Blitar sepanjang tahun menuju pada tanggal 1 Juni. Goro-goro atau pesan moral bertujuan untuk menyampaikan aspirasi rakyat dengan mengkritik baik-buruknya Pemerintah Kota Blitar selama kepengurusannya. Kritikan tersebut bersifat membangun untuk kehidupak Pemerintah 
dan masyarakat Kota Blitar lebih baik kedepannya. Prosesi ini mencerminkan nilai Nasionalisme yang sudah melekat pada masyarakat di Kota Blitar dengan memiliki kesadaran untuk memberikan aspirasinya agar Negara Indonesia bisa lebih baik dan lebih maju. Pada Upacara Budaya ini juga masih menjunjung warisan budaya lokal dengan menggunakan iringan musik karawitan dan Bahasa Jawa hampir diseluruh rangkaian Upacara Budaya.

Goro-goro merupakan kritikan terhadap pemerintah, hal ini tidak adil. Kritikan harusnya ditujukan kepada segenap bangsa Indonesia, dan bukan hanya kepada pemerintah saja. Nasionalisme warga kota Blitar sudah mendarah daging. Hal ini masih perlu diragukan mengingat Kepala Daerah Kota Blitar di tangkap KPK, diadili, dihukum dan dipecat karena melakukan kejahatan. Korupsi adalah contoh tindakan yang tidak berjiwa Nasionalisme. Korupsi sebagai wujud tindakan yang tidak menghianati jiwa Nasionalisme bangsa Indonesia berdasarkan Pancasila. Pemimpin berasal dari gua garba masyarakat. Adanya pemimpin yang tidak baik, patut diduga masyarakat yang melahirkan pemimpin tersebut juga kurang baik. Maka dari itu masyarakat harus bertrasedensi bersama-sama untuk menjadi lebih baik.

\section{Prosesi Keempat Ritus Kirab Gunungan Lima}

Pembuatan Gunungan Lima diawali dengan ritual Attasila (ajaran agama Budha) yang dilaksanakan pada hari-hari Uposatha yakni bertepatan pada 1, 8, 15, 23 pada perhitungan tarikh luar maupun penanggalan bulan. Ritual ini berisi delapan aturan moral yang di dalamnya ada anjuran untuk berpuasa sesudah jam 12. 00 siang sampai subuh besok hari. Tujuannya adalah untuk mengalahkan rasa lapar serta menahan diri dari berbagai perbuatan buruk manusia.

Selesai ritual Attasila dilakukan selanjutnya adalah mempersiapkan sesajen. Sesajen yang sudah disiapkan ditaruh berdampingan dengan Bathara Kala. Bathara Kala mempunyai makna guru terbaik, dengan harapan dalam pelaksanaa ritus Grebeg Pancasila bisa berjalan lancar. Selanjutnya adalah pembuatan gunungan lima. Gunungan lima ini berjumlah 5 dengan besar kurang lebih 1,5meter dengan wujud yang lancip dan mengerucut ke atas, yang berarti bahwa manusia hanya menyembah Tuhan Yang Maha Esa sebagai puncak tertinggi yang menguasai alam semesta. Gunungan berbentuk mengerucut sebagai simbol keberadaan Tuhan yang terletak pada tempat yang tinggi dan teratas. Gunungan lima berjumlah 5 sebagai simbol dari 5 sila Pancasila.

Komponen dari Gunungan Lima diantaranya adalah ontong atau jantung pisang, sebagai simbol dari jantung yang mempunyai makna hati nurani yang bersih dan legowo (bentuk keikhlasan). Jeruk dan cabai, simbol rasa asam, getir serta pedas ialah cerminan dari perjalanan hidup, yang tidak selalu manis. Hal ini juga berkaitan dengan ekspedisi menggali Pancasila dimana menghadapi berbagai rintangan. Wortel dilambangkan sebagai akulturasi budaya luar ataupun kebudayan asing yang bisa diterima di Indonesia ketika dirasa cocok dengan budaya Indonesia. Kacang panjang, simbol dari kehidupan yang lurus karena adanya arah ataupun peraturan, dimana peraturan tersebut merupakan undang- undang. Bawang putih simbol dari ayah dan bawang merah simbol dari ibu, bermakna bahwa dalam hidup manusia wajib senantiasa mengingat dari mana asal manusia itu tiba, serta kemana manusia hendak berangkat. Sawi putih hasil bumi yang ditaruh pada bagian dasar Gunungan Lima, dilambangkan sebagai pelataran negara yang mencerminkan bahwa Indonesia adalah negara Agraris dengan hasil pertanian.

Pada kirab Gunungan Lima tercermin nilai Gotong Royong dimana pada persiapan pembuatan Gunungan Lima dilakukan secara bergotong royong oleh masyarakat di Kota Blitar. Setiap masyarakat memiliki sumbangsih terhdap persiapan pembuatan Gunungan Lima. Adanya nilai Gotong royong tidak hanya tercermin pada proses persiapannya tetapi juga pada proses pelaksanaannya. Pada Kirab Gunungan Lima semua masyarakat di Kota Blitar turut serta terlibat. Hal ini menunjukkan bahwa masyarakat di Kota Blitar antusias untuk terus mempertahankan serta mencintai bangsa dan negaranya sendiri. Nilai Gotong royong tersebut juga menunjukkan adanya solidaritas sesama untuk mencapai keinginan bersama tanpa memikirkan keuntungan diri sendiri, melainkan mempertimbangkan keuntungan dan kebahagiaan bersama.

Nilai keberaniaan, kepahlawanan atau patriotik juga tercermin disini. Hal ini menunjukkan bahwa dalam melakukan penggalian Pancasila harus dengan sikap keberanian dan rela berkorban. Keberanian terlihat dari Bung Karno berani berpidato tentang nilai-nilai Pancasila ditengah 
masyarakat Indonesia yang terjajah (Atmaja \& Basundoro, Desember 2013). Sila kedua dari Pancasila yang tertulis Kemanusiaan yang Adil dan Beradab adalah satu nilai dari Pancasila yang berperikemanusiaan anti penjajahan. Bung Karno mendeklarasikan anti penjajahan dan hak untuk merdeka dalam sepanjang waktu perjuangannya. Bung Karno sadar terhadap resiko yang bakal menimpa, yaitu ditangkap, diadili, dipenjarakan bahkan dihukum mati.

\section{Prosesi Kelima Ritus Kenduri Pancasila}

Prosesi terakhir adalah ritus Kenduri Pancasila, adalah genduren (dalam bahasa Jawa) tasyakuran dengan menghidangkan tumpeng dan berbagai makanan, dalam pelaksanaanya dilakukan dengan cara duduk lesehan. Ritus ini menggambarkan sebuah cara dari pemerintah yang memiliki tujuan untuk mendekatkan antara masyarakat dengan para petinggi pemerintahan. Disamping itu sebagai alat pemersatu agar tidak terjadi ketimpangan sosial dalam kehidupan bermasyarakat. Ritus ini dihadiri peserta dari berbagai lintas agama yang menandakan bahwa masyarakat Kota Blitar hidup rukun, damai, dan menjunjung tinggi toleransi dalam beragama. Kenduri atau slametan memiliki fungsi sosial yang dapat digunakan sebagai kontrol sosial (pengendali sosial) antar masyarakat. Makna dari Kenduri Pancasila sebagai bentuk rasa syukur karena telah diberi kelancaran dalam seluruh rangkaian pelaksanaan tradisi Upacara Grebeg Pancasila. Dilihat dari seluruh rangkaian prosesi dari tradisi Tradisi Grebeg Pancasila memberikan pengaruh baik terhadap persatuan dan kesatuan bangsa Indonesia. Hal ini terlihat dari makna-makna yang terkandung dalam setiap prosesinya. Berbagai nilai Pancasila dihayati dan ditanamkan dalam tradisi ini, terlebih pada nilai religius dan nasionalisme yang digotong masyarakat. Nilai Religius dan nilai Nasionalisme yang tinggi pada masyarakat Kota Blitar harus terus dipertahankan sehingga perpecahan antar sesama dapat dihindari (Basit, 2020).

Ritus Kenduri melakukan makan bersama antara masyarakat dan pejabat tuntuk meningkatkan persatuan dan kesatuan. Kenduri tumpeng merupakan makanan mulut dan perut. Ideologi Pancasila adalah makanan mental spiritual. Hendaknya dapat dibedakan dengan jelas bahwa makanan mental spiritual tidak simetris dengan makanan mulut dan perut. Persatuan dan Kesatuan bangsa Indonesia. Proses menjadi satu dan menjadi satu harus didasarkan satu ideologi. Ideologi tidak bisa terbatas dimaknai dengan simbolis tumpeng. Persatuan dan kesatuan harus didasarkan kepada konsep kebangsaan Indonesia Pancasila dan kemerdekaan. Disanalah satu sisi konsep kebangsaan Indonesia menurut Bung Karno adalah satu persamaan hidup berasal dari yang maha hidup. Meskipun manusia berbeda beda dalam segala karakter fisik atau budaya namun memiliki roh hidup berasal dari yang maha hidup yang satu, "Nasionalisme Indonesia memiliki rasa hidupnya sebagai suatu pedoman. Dan Nasionalisme Indonesia menjalankan rasa hidupnya sebagai suatu dedikasi".

\section{KESIMPULAN}

Tradhisi Grebeg Pancasila memiliki hubungan sangat erat kaitannya dengan nilai-nilai Pancasila. Makna tersebut tersirat dalam setiap prosesi pelaksanaannya. Pada prosesi Bedhol Pusaka Nagari, arak-arakan dilakukan oleh Bregodo Siji, Bregodo Enem dan Bregodo Patang Puluh Lima, dengan artian mengingat kembali 1 Juni 45 adalah lahirnya Pancasila. Nilai yang terkandung didalamnya adalah masyarakat di Kota Blitar saling bekerja bersama-sama dan bahu membahu jalannya kegiatan, yang menandakan adanya nilai gotong royong dan Persatuan didalamnya. Prosesi Kedua Ritus Malam Tirakatan, arti filosofis dari ritus Tirakatan ialah sebagai perenungan, dan menghayati Pancasila selaku nilai-nilai luhur bangsa Indonesia. Prosesi Ketiga Ritus Upaca Budaya, Prosesi ini mencerminkan nilai Nasionalisme dengan memiliki kesadaran untuk memberikan aspirasinya agar Negara Indonesia bisa lebih baik dan lebih maju. Prosesi Keempat Ritus Kirab Gunungan Lima Gunungan Lima Wujud Gunungan lima yang lancip serta menguncup ini mempunyai arti jika manusia berserah diri dan menyembah hanya kepada Tuhan Yang Maha Esa. Gunungan dalam upacara Grebeg Pancasila sebagai simbol keberadaan Tuhan yang terletak pada tempat tertinggi dan teratas. Gunungan lima berasal dari jumlah sila sila 5. Pada kirab Gunungan Lima tercermin nilai Gotong Royong dimana pada persiapan pembuatan Gunungan Lima dilakukan secara bergotong royong oleh masyarakat di Kota Blitar. Nilai Gotong royong tersebut juga menunjukkan adanya solidaritas sesama untuk mencapai keinginan bersama tanpa memikirkan keuntungan diri 
sendiri, melainkan mempertimbangkan keuntungan dan kebahagiaan bersama. Ritus kelima merupakan Kenduri Pancasila diselenggarakan dengan duduk lesehan, dengan tujuan buat mendekatkan warga dengan para pejabat, serta menggambarkan pemersatu agar tidak terjalin kesenjangan antara pejabat serta warga. Pada ritus Kenduri Pancasila diundangan pula partisipan dari lintas agama, dimana perihal ini meyakinkan kalau warga Blitar rukun serta damai. Arti dari Kenduri Pancasila wujud rasa syukur, sebab telah diberi kelancaran dalam melakukan Upacara Grebeg Pancasila secara totalitas. Tergambar jelas disini bahwa adanya Tradisi Grebeg Pancasila memberikan pengaruh baik terhadap persatuan dan kesatuan bangsa Indonesia. Nilai-nilai yang sudah berhasil digali maknanya perlu untuk senantiasa dilestarikan dalam kehidupan berbangsa dan bernegara sebagai bentuk warisan budaya.

\section{DAFTAR PUSTAKA}

Atmaja, A. K., \& Basundoro, P. (Desember 2013). Makna Simbolik Makam Bung Karno di Blitar. Jurnal Kesejarahan Vol. 3, No.1, 89-96.

Basit, A. (2020). Nilai-nilai Filosofis dalam Upacara Grebeg Pancasila di Kota Blitar (Tinjauan Filsafat Nilai Max Scheler). Tulungagung: Filsafat Agama. Thesis Pascasarjana. Institut Agama Islam Negeri Tulungagung.

Bintarto. (1989). Interaksi Desa-Kota. Jakarta: Ghalia Indonesia.

Daldjoeni. (1978). Seluk Beluk Masyarakat Kota; Pusparagam Sosiologi Kota. Bandung: Alumni.

Kaelan. (2002). Filsafat Pancasila Pandangan Hidup Bangsa Indonesia. Yogyakarta: Paradigma.

Kattsoff, L. (2004). Pengantar Filsafat. Yogyakarta: Tiara Wacana Yogyakarta.

Khotimah, K. (2011). Upacara Grebeg Pancasila dalam Upaya Pengembangan Nilai-Nilai Nasionalisme di Kota Blitar. Skripsi. Malang: Universtas Negeri Malang.

Koentjaraningrat, P. D. (2015). Pengantar IImu Antropologi. Jakarta: Rineka Cipta.

Maulana, M. S. (2014). Tradisi Bantengan dan Modernisasi (Studi Eksistensi Tradisi Bantengan di Dusun Banong Desa Gerbangsari Kecamatan Jatirejo Kabupaten Mojokerto. Skripsi Prodi Sosiologi Fakultas Dakwah dan IImu Komunikasi . Surabaya: Universitas Islam Negeri Sunan Ampel Surabaya.

Muljana, S. (2008). Kesadaran Nasional dari Kolonialisme sampai Kemerdekaan Jilid 1. Yogyakarta: LKIS.

Mulyana, R. (2004). Mengartikulasikan Pendidikan Nilai. Bandung: Alfabeta.

Peursen, C. (1988). Strategi Kebudayaan. Yogyakarta: Kanisisus.

Putriana, D., \& Warsono. (2019). Grebeg Pancasila Sebagai Sarana Penanaman Nilai-Nilai Pancasila (Studi Kasus di Kota Blitar). Kajian Moral dan Kewarganegaraan Volume 7 Nomor 02, 12371252.

Rohmah, H. A. (2019). Pengembangan Nilai Nasionalis Siswa dalam Pembelajaran IPS (Studi Kasus di SMPN 1 Wlingi-Blitar). Blitar: Pendidikan IPS. Thesis Pascasarjana. Universitas Pendidikan Indonesia.

Sari, D. A. (2014). Kajian Nilai Max Scheler dalam Upacara Grebeg Maulud Keraton Surakarta. Yogyakarta: Universitas Gadjah Mada.

Sumitrasari, D. (2012). Makna Simbolik Kirab Gunungan Limo Pada Ritual Grebeg Dalam Peringatan Hari Lahir Pancasila Di Kota Blitar. Malang: Skripsi, Jurusan Seni dan Desain, Fakultas Sastra, Universitas Negeri Malang.

Sutarjo Adisusilo, J. (2012). Pembelajaran Nilai-Nilai Karakter Konstruktivisme dan VCT sebagai Inovasi Pendekatan Pembelajaran Afektif. Jakarta: Rajawali Pers.

Sztompka, P. (2007). Sosiologi Perubahan Sosial. Jakarta: Prenada Media Grup.

Ubaedillah, \& Rozak, A. (2013). Pancasila, Demokrasi, HAM, dan Masyarakat Madani. Jakarta: Prenadamedia Group.

Zummi, N. Q. (2016). Kajian Makna dan Nilai Karakter pada Ritus Grebeg Pancasila di Kota Blitar serta Keterkaitannya bagi Pendidikan IPS. Skripsi Fakultas IImu Sosial. Malang: Universitas Negeri Malang. 